Short Communication

\title{
D-loop haplotype diversity in Brazilian horse breeds
}

Patrícia Ianella ${ }^{1}$, Maria do Socorro Maués Albuquerque ${ }^{1}$, Samuel Rezende Paiva ${ }^{1}$, Andréa Alves do Egito ${ }^{2}$, Leonardo Daniel Almeida ${ }^{1}$, Fabiana T. P. S. Sereno ${ }^{3}$, Luiz Felipe Ramos Carvalho ${ }^{4}$, Arthur da Silva Mariante ${ }^{1}$ and Concepta Margaret McManus ${ }^{3}$

${ }^{1}$ Embrapa Recursos Genéticos e Biotecnologia, Parque Estação Biológica, Brasília, DF, Brazil.

${ }^{2}$ Embrapa Gado de Corte, Campo Grande, MS, Brazil.

${ }^{3}$ Faculdade de Agronomia e Medicina Veterinária, Universidade de Brasília, Campus Darcy Ribeiro, Brasília, DF, Brazil.

${ }^{4}$ Ministério da Agricultura, Pecuária e Abastecimento, Brasília, DF, Brazil.

\begin{abstract}
:
The first horses were brought to Brazil by the colonizers after 1534. Over the centuries, these animals evolved and adapted to local environmental conditions usually unsuitable for exotic breeds, thereby originating locally adapted Brazilian breeds. The present work represents the first description of maternal genetic diversity in these horse breeds based on D-loop sequences. A D-Loop HSV-I fragment of 252 bp, from 141 horses belonging to ten Brazilian breeds / genetic groups (locally adapted and specialized breeds) were analysed. Thirty-five different haplotypes belonging to 18 haplogroups were identified with 33 polymorphic sites. Haplotype diversity (varying from 0.20 to 0.96 ) and nucleotide diversity (varying from 0.0039 to 0.0239 ) was lower for locally adapted than for specialized breeds, with the same pattern observed for $F_{S T}$ values. Haplogroups identified in Brazilian breeds are in agreement with previous findings in South American samples. The low variability observed mainly in locally adapted breeds, indicates that, to ensure conservation of these breeds, careful reproductive management is needed. Additional genetic characterization studies are required to support accurate decision-making.
\end{abstract}

Keywords: mitochondrial DNA, genetic characterization, Equus caballus, locally adapted breeds, animal genetic resources.

Received: June 13, 2016; Accepted: March 25, 2017.

Horses have played an important role in shaping human civilization and their domestication occurred from several wild populations 4.000 to 6.000 years ago (Vaughan et al., 2010; Outram et al., 2009). This species was introduced in South America by European conquerors during the 16th century, and the development of current American horse breeds has been based on the ones from the Iberian Peninsula (Jimenez et al., 2012; Cortés et al., 2017). As with all domesticated animals introduced during this period, horses were widely dispersed in this new environment, becoming adapted to different conditions (Mirol et al., 2002). The first horses were brought to Brazil by the colonizers after 1534 (Primo, 2004). Over the centuries these animals evolved and adapted to conditions usually unsuitable to exotic breeds, including local environmental (high temperatures, long periods of drought), sanitary (vector-born disease) and management systems found in Brazil,

Send correspondence to Patrícia lanella. Laboratório de Genética Animal / PCG - Prédio da Conservação de Germoplasma, Embrapa Recursos Genéticos e Biotecnologias. Parque Estação Biológica PqEB, 70770-901Brasília, DF, Brazil. E-mail: patrícia.ianella@embrapa.br. originating Brazilian breeds also known as "locally adapted" or "creoles". The main locally adapted Brazilian genetic groups include the breeds Campeira (Santa Catarina), Creole (Rio Grande do Sul), Lavradeira (Roraima), Pantaneira (Pantanal - Mato Grosso), Mangalarga (Minas Gerais and São Paulo), Marajoara (Marajó Island - Pará), as well as smaller animals such as the Puruca pony (Pará) and the genetic group Baixadeiro (Maranhão). More recently, to improve conformation, and increase stature, these breeds were crossed with Arab or English Thoroughbred breeds (Beck, 1985). Considering the importance of these breeds/genetic groups in their respective geographic regions and set the hypothesis that they are facing a genetic erosion, the main objective of this study is to quantify the genetic distribution of mtDNA haplotypes of the locally adapted breeds and genetic groups from Brazil and compare this with the information already generated for specialized breeds.

Genetic characterization of cryopreserved and live animals is an important approach for orientating conservation strategies (Solis et al., 2005). Mitochondrial DNA (mtDNA) sequencing has imprinted biogeographic and phylogenetic perspectives on intra- and inter-species ge- 
netic structure. The displacement loop hyper-variable region of mtDNA (D-loop) is useful for population and evolutionary studies because of its high level of sequence variation, in addition to a lack of recombination and maternal heritance. D-loop polymorphisms have been used to understand the origin and genetic diversity of horses from Italy (Bigi et al., 2014), Iran (Moridi et al., 2013), India (Devi and Ghosh, 2013), China (Zhang et al., 2012), Colombia (Jimenez et al., 2012), Croatia (Ivankovic et al., 2009) and Lithuania (Cothran et al., 2005), as well as Lusitano (Hill et al., 2002; Lopes et al., 2005) and Arabian horses (Khanshour and Cothran, 2013). These studies have also been used to infer on horse phylogeography and evolution (Jansen et al., 2002; Mirol et al., 2002; McGahern et al., 2006; Cieslak et al., 2010; Achilli et al., 2012; Jimenez et al., 2012; Devi and Ghosh, 2013). According to Mirol et al. (2002), knowledge of South American breeds is important for conservation genetics of domestic horses, as New World varieties are, probably, closer to historical horses than those found currently on the Iberian Peninsula, which have been crossed with other breeds over the last 500 years. In spite of the wide range of Brazilian locally adapted breeds, few studies have been carried out with microsatellite data to investigate their genetic diversity and establish relationships between them. Most of the data indicated loss if variability for Brazilian locally adapted breeds (Reis et al., 2008; De Assis et al., 2009; Silva et al., 2012; Pires et al., 2016), except in the Pantaneiro breed, for which relatively high levels of heterozygosity were found (Giacomoni et al., 2008; Sereno et al., 2008).

To investigate mtDNA diversity in specialized (commercial breeds) and locally adapted breeds (creoles) of horses in Brazil, 141 animals belonging to 10 locally adapted and commercial Brazilian breeds/genetic groups were analysed (Table 1). Analyses of sequences from the HVS-I region of the mitochondrial D-Loop sequence (Ishida et al.,
2009) were carried out. PCR reactions were performed in a $20 \mu \mathrm{L}$ final volume containing: $9 \mathrm{ng}$ of DNA, $0.25 \mu \mathrm{m}$ of each primer, $0.20 \mathrm{mM}$ dNTP, $1 \mathrm{X}$ PCR buffer (1M Tris HCL, pH $8.4100 \mathrm{mM}$, KCL $500 \mathrm{mM}$ ), $2.5 \mathrm{mM} \mathrm{MgCl}_{2}, 1 \mathrm{U}$ Taq polymerase. Amplifications started with an initial denaturation step of $94^{\circ} \mathrm{C}$ for $5 \mathrm{~min}$, followed by 35 cycles of $1 \mathrm{~min}$ at $94^{\circ} \mathrm{C}, 59^{\circ} \mathrm{C}$ for $1 \mathrm{~min}, 72^{\circ} \mathrm{C}$ for $1 \mathrm{~min}$, and a final extension of $5 \mathrm{~min}$ at $72{ }^{\circ} \mathrm{C}$. PCR products were purified with Exo-SAP enzyme and sequenced using a BigDye v3.1 sequencing kit (Applied Biosystems, Foster City, CA, USA) and a DNA sequencer ABI 3130 (Applied Biosystems) according to the manufacturer's manual.

The sequences obtained were aligned with the reference sequence (GenBank Accession number NC_001640) using SeqScape v2.6, as well as other sequences deposited in GenBank. After edition, the sequences ( $252 \mathrm{bp} / \mathrm{animal})$ were analyzed in MEGA V.3.1 (Kumar et al., 2004) and DNASP V.4.5 (Rozas et al., 2003) programs to determine the number of haplotypes. Haplotypes were classified in haplogroups according to the nomenclature established by Achilli et al. (2012). The analysis of Molecular variance (AMOVA) and $F s t$ distances between pairs of breeds were carried out using the Arlequin V. 3.0 (Excoffier et al., 2005) program. Free software NETWORK 5.0.0.1 (http://www.fluxus-engineering.com) was used for calculation of the median joining network (Bandelt et al., 1999) of all haplotypes.

Thirty-six different haplotypes were identified with 33 polymorphic sites (Table 2). Of the 18 haplogroups found by Achilli et al. (2012), nine (A, B, H, I, L, M, N, O'P' and Q) were found in the Brazilian samples, and seven (except $\mathrm{H}$ and O'P') were identified in the locally adapted breeds/genetic groups (Table 2 and Figures 1 and 2). Achilli et al. (2012) have also identified these same haplogroups in South American samples, except for the $\mathrm{H}$ haplogroup, a rare type observed only in Asia and Europe (here observed

Table 1 - Estimated haplotype and nucleotide diversity from the d-loop region of mtDNA, in locally adapted and specialized Brazilian horse breeds.

\begin{tabular}{lccccc}
\hline Breed & Number of animals & Number of haplotypes & Haplotype diversity & Nucleotide diversity & $F_{\text {ST }}$ \\
\hline Baixadeira (EBA) & 10 & 3 & $0.600 \pm 0.131$ & $0.01667 \pm 0.00637$ & 0.015 \\
Campeira (ECA) & 10 & 3 & $0.600 \pm 0.132$ & $0.00899 \pm 0.00462$ & 0.008 \\
Lavradeira (ELV) & 10 & 2 & $0.200 \pm 0.154$ & $0.00397 \pm 0.00314$ & 0.004 \\
Marajoara (EMA) & 10 & 4 & $0.778 \pm 0.091$ & $0.01437 \pm 0.00521$ & 0.013 \\
Puruca (EPU) & 10 & 5 & $0.756 \pm 0.130$ & $0.01120 \pm 0.00579$ & 0.009 \\
Pantaneira (EPA) & 43 & 16 & $0.909 \pm 0.025$ & $0.01787 \pm 0.00614$ & 0.018 \\
Criolla (ECR) & 11 & 5 & $0.733 \pm 0.155$ & $0.00661 \pm 0.00361$ & 0.002 \\
Arab (EAR) & 12 & 9 & $0.962 \pm 0.040$ & $0.02260 \pm 0.01149$ & 0.023 \\
Mangalarga (EML) & 9 & 7 & $0.944 \pm 0.070$ & $0.02116 \pm 0.00859$ & 0.020 \\
English Thoroughbred (ETB) & 16 & 12 & $0.942 \pm 0.048$ & $0.02394 \pm 0.01198$ & 0.025 \\
Total & 141 & 33 & 0.9250 .011 & $0.01942 \pm 0.00672$ & 0.022 \\
\hline
\end{tabular}

Fst - Fixation Index 


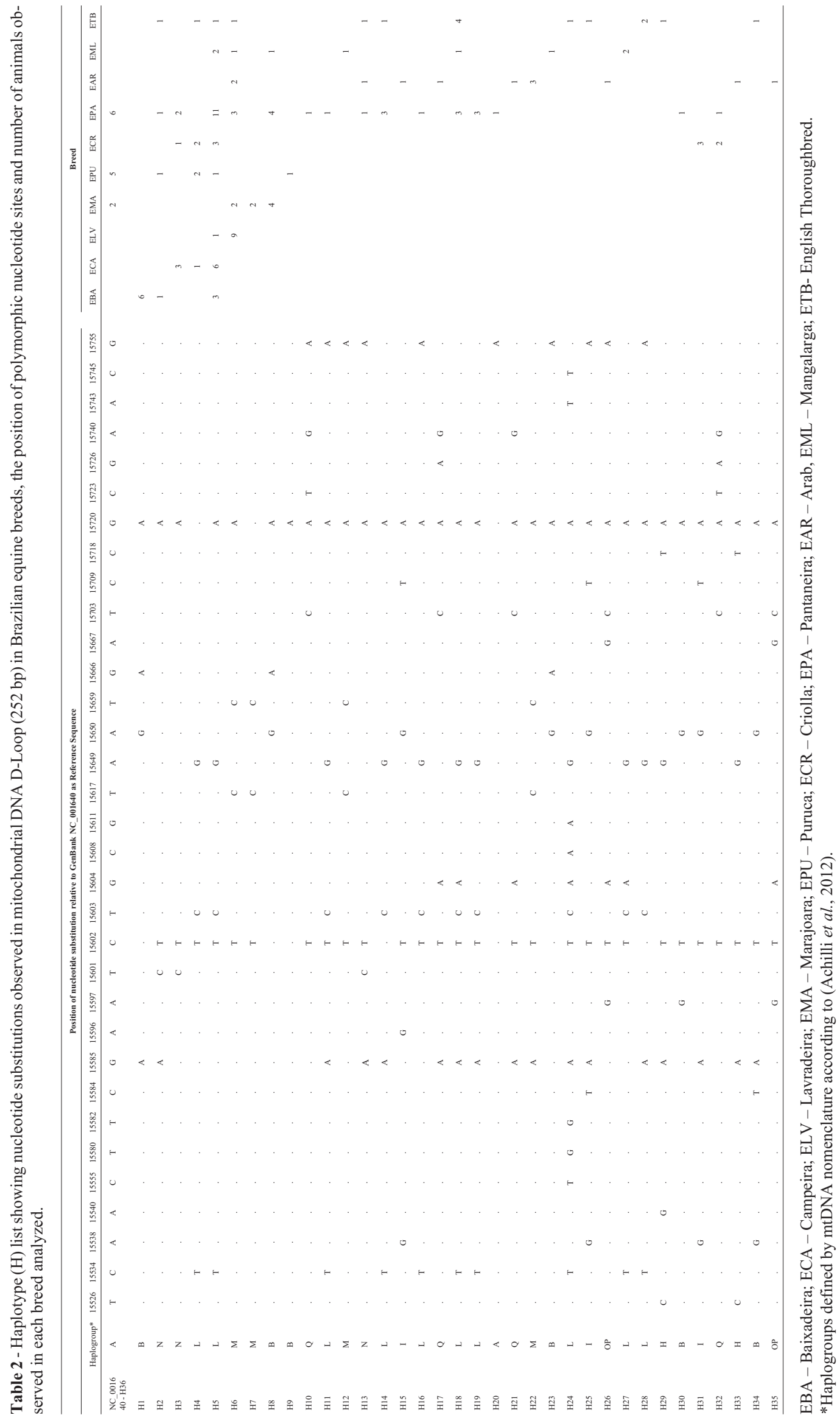




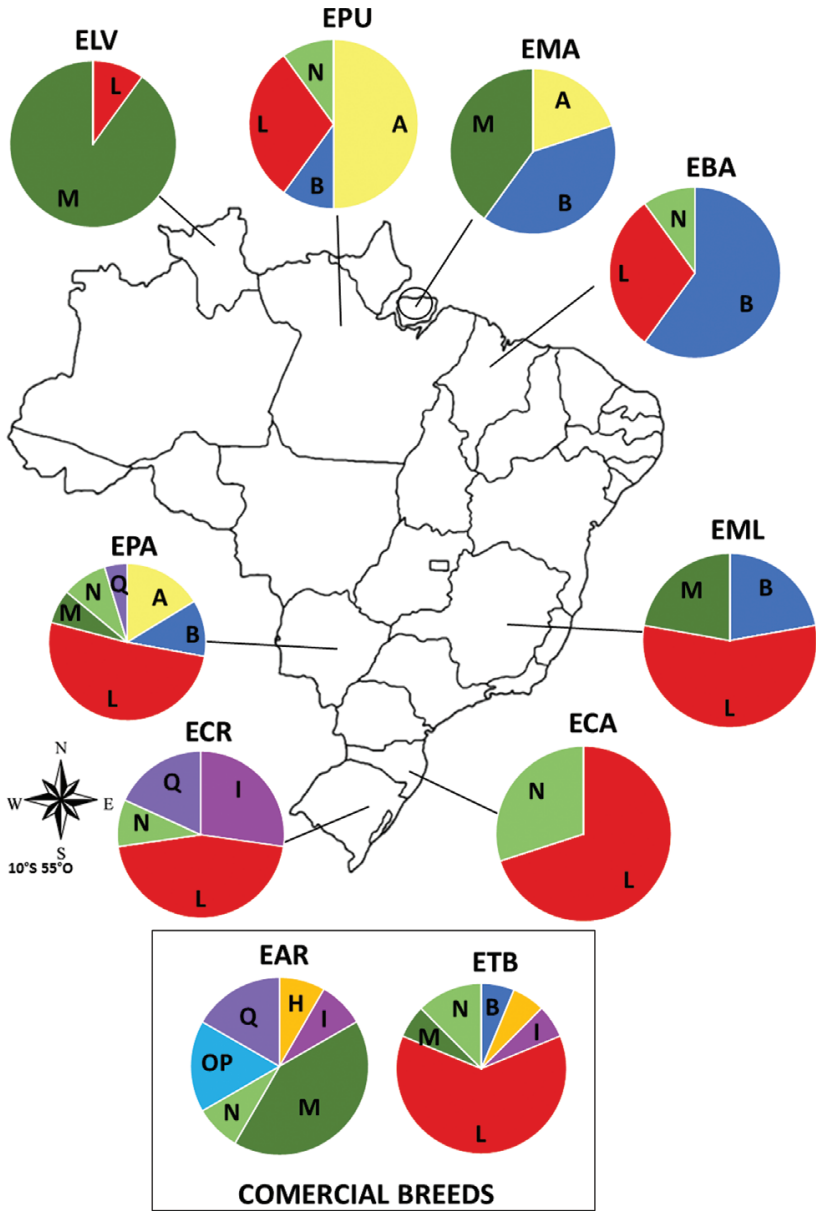

Figure 1 - Haplogroup frequency in Brazilian horse breeds. Haplogroup classification is according to Achilli et al. (2012). Horse Breeds: ELV Lavradeira; EPU - Puruca; EMA - Marajoara; EBA - Baixadeira; EPA Pantaneira; ECR - Crioula; EML - Manga Larga; ECA - Campeira; EAR Árabe; ETB - English Thoroughbreed.

in one EAR and one ETB). These authors have proposed a new nomenclature, constituting 18 haplogroups observed in ancient and modern horses worldwide. All these haplogroups are present in Asian horses and 17 in European horses (except for $\mathrm{F}$ - present only in Przewalskis horse, an Asian subspecies wild horse).

The majority of mtDNA sequences from Brazilian locally adapted breeds belong to haplogroup L (Haplotype H5, 28 individuals, Figure 2) although this haplogroup was not found in locally adapted Marajoara (EMA) and specialized Arab (EAR) breeds (Table 1). The EMA breed is found on an island (Marajó) off the coast of Pará state in northern Brazil. Given its isolation, there are less opportunities for crossbreeding moreover the island has a largely inhospitable terrain, such as flooded marshlands (Reis et al., 2008) with high indices of tropical diseases, such as IEA (Equine infectious anemia). The O'P' haplogroup was observed only in the Arab breed. The number of haplotypes per breed varied between two (Lavradeira-ELA) and 16 (PantaneiraEPA) (Table 2). Twenty-five unique haplotypes were ob- served in the locally adapted breeds/genetic groups: EMA and Creole (ECR) Baixadeira (EBA), showing one each, and EPA showing seven unique haplotypes. Specialized breeds, such as EAR and Thoroughbred (ETB) showed seven and five unique haplotypes, respectively (Table 1). To better understand how haplotypes are distributed across the breeds, a network analysis for the 36 haplotypes was carried out (Figure 2). This analysis corroborates with the haplogroup classification, showing the separation of the haplotypes into haplogroups according to the branches of the network.

According to Reis et al. (2008), Marajora (EMA) had slightly higher diversity than Puruca (EPU), as also observed in this study. Such a finding may be due to a larger population and broader founder base. According to Reis et al. (2008), the Marajoara horses was derived from Portuguese horses from Cabo Verde, introduced into the Marajó archipelago at the beginning of the 18th century, while the Puruca pony was derived from nine Shetland ponies imported from France at the end of the 19th century.

The haplotype diversity index (Table 1 ) was highest for EAR (0.962) and lowest for ELV (0.200). EPA showed the highest haplotype diversity among the locally adapted breeds $(0.900)$. The lowest nucleotide diversity was observed as well in ELV (0.00397) and the highest in EPA (0.1787) among the locally adapted breeds. The specialized breed ETB showed the highest nucleotide diversity index among the breeds analyzed (0.02394). The observed haplotype and nucleotide diversity average in this study was lower than that recorded in Italian (Bigi et al., 2014), Indian (Devi and Ghosh, 2013), Colombian Creole (Jimenez et al., 2012) and Chinese horses (Zhang et al., 2012). The ELV showed the lowest haplotype and nucleotide diversity index, and the individuals of this studied population grouped only in two haplogroups, which may be related to its geographic isolation. EPA showed the highest diversity indices among local breeds., and it has mtDNA classified in six haplogroups with three shared haplotypes H13, H14 and H18 with specialized breeds. These findngs may be due to the use of the breed in different crosses with specialized breeds in an attempt to increase the physical stature and improve performance. In addition, it is important to note that EPA is the most prominent locally adapted breed in Brazil, and it has a growing trend in the internal market. Such high genetic variability was also observed in other studies using RAPD (Egito et al., 2007) and microsatellite markers (Giacomoni et al., 2008; Sereno et al., 2008).

Values of breed differentiation $\left(F_{S T}\right)$ were expectedly low, varying between breeds (from 0.002 in ECR to 0.025 in ETB, mean 0.02), suggesting a low population structure level (Table 1). Silva et al. (2012), using microsatellites to characterize locally adapted horse breeds, demonstrated loss of genetic variability in Campeira, Lavradeira, Baixadeira and Mangalarga Marchador horses in Brazil. Similar results were described using microsatellite analyses in Ma- 


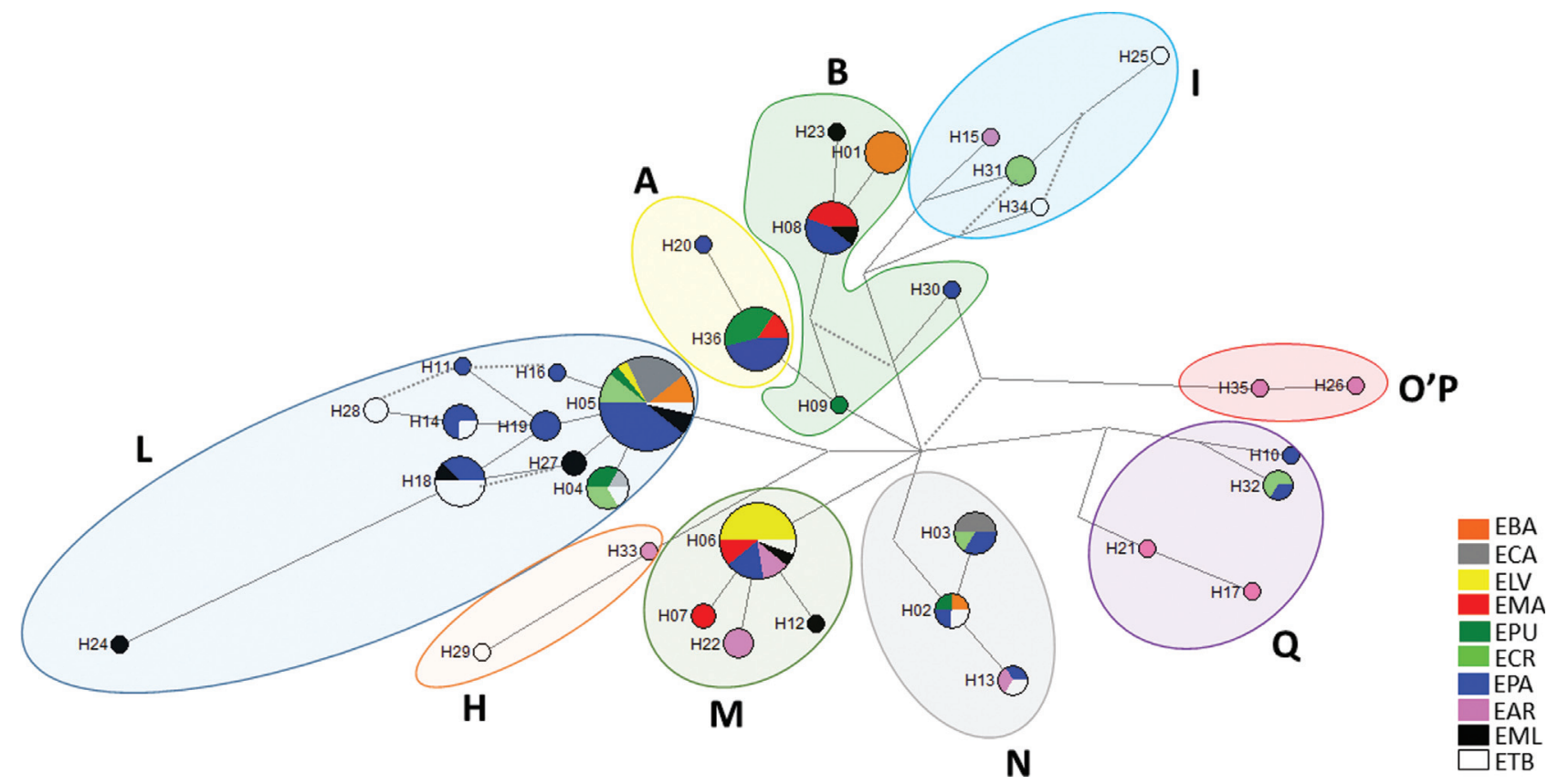

Figure 2 - Median-joining network analysis of 36 haplotypes from 141 Brazilian horse mitochondrial DNA. Circles represent the haplotypes, and their sizes are proportional to the frequency. Colored shapes represent haplogroup classification according to Achilli et al. (2012). Horse Breeds: ELV Lavradeira; EPU - Puruca; EMA - Marajoara; EBA - Baixadeira; EPA - Pantaneira; ECR - Crioula; EML - Manga Larga; ECA - Campeira; EAR - Árabe; ETB - English Thoroughbreed.

rajoara and Puruca (Reis et al., 2008) and Mangalarga breeds (De Assis et al., 2009). This highlights the need for conservation efforts for these breeds, especially those found in highly challenging environments where tropical diseases can devastate local populations and severely affect subsistence farmers who depend on these animals for their living.

Haplogroups identified in Brazilian breeds are in concordance with previously findings in South American samples, as described in the literature. Despite the important adaptive characteristics retained in these breeds altogether, a loss of genetic variability can be seen. Locally adapted breeds, except Pantaneira, tend to show lower haplotype diversity than commercial breeds. This may be associated with their history of geographical isolation, such as for Lavradeira and Marajoara, local adaptations to stressful environmental conditions (most locally adapted breeds), or long term breeding strategies, such as with the Crioula, for which a herd book has been maintained for almost 100 years (Maciel et al., 2014).

Genetic diversity is essential to maintain current production needs in several environments, allowing sustained genetic improvement and facilitating faster adaptation to changing breeding objectives (Notter, 1999). Careful selection of animals for breeding and conservation should be carried out to ensure that variability is maintained within these populations. Paiva et al. (2011) showed that the integration of different genetic strategies is useful in conservation programs to provide different types of information and so optimize the selection of animals for breeding purposes.
The mtDNA haplotypes, along with nuclear molecular markers, may be important as an additional criterion for genetic management of animals in conservation nuclei, as well as a proxy to help the germplasm collection to be deposited in the national gene bank.

\section{Acknowledgments}

This work has been supported by the Brazilian Ministry of Agriculture, Livestock and Food Supply (MAPA).

\section{References}

Achilli A, Olivieri A, Soares P, Lancioni H, Hooshiar Kashani B, Perego UA, Nergadze SG, Carossa V, Santagostino M, Capomaccio S, et al. (2012) Mitochondrial genomes from modern horses reveal the major haplogroups that underwent domestication. Proc Natl Acad Sci U S A 109:2449-2454.

Bandelt HJ, Forster P and Röhl A (1999) Median-joining networks for inferring intraspecific phylogenies. Mol Biol Evol 16:37-48.

Beck S (1985) Eqüinos: Raças, Manejo e Equitação. 2nd ed. Editora dos Criadores, São Paulo, 373 p.

Bigi D, Perrotta G and Zambonelli P (2014) Genetic analysis of seven Italian horse breeds based on mitochondrial DNA D-loop variation. Anim Genet 45:593-595.

Cieslak M, Pruvost M, Benecke N, Hofreiter M, Morales A, Reissmann M and Ludwig A (2010) Origin and history of mitochondrial DNA lineages in domestic horses. PLoS One 5:e15311.

Cortés O, Dunner S, Gama LT, Martínez AM, Delgado JV, Ginja C, Jiménez LM, Jordana J, Luis C, Oom MM, et al. (2017) The legacy of Columbus in American horse populations as- 
sessed by microsatellite markers. J Anim Breed Genet 134:340-350.

Cothran EG, Juras R and Macijauskiene V (2005) Mitochondrial DNA D-loop sequence variation among 5 maternal lines of the Zemaitukai horse breed. Genet Mol Biol 28:677-681.

De Assis JB, DeLaat DM, Peixoto MGCD, Bergmann JAG, Fonseca CG and Carvalho MRS (2009) Genetic diversity and population structure in Brazilian Mangalarga Marchador horses. Genet Mol Res 8:1519-1524.

Devi KM and Ghosh SK (2013) Molecular phylogeny of Indian horse breeds with special reference to Manipuri pony based on mitochondrial D-loop. Mol Biol Rep 40:5861-5867.

Egito AA, Fuck BH, McManus C, Rezende S, Maués S, Santos SA, Gomes U, Abreu P De, Augusto J, Tavares F, et al. (2007) Genetic variability of Pantaneiro horse using RAPD-PCR markers. Rev Bras Zootec 36:799-806.

Excoffier L, Laval G and Schneider S (2005) Arlequin (version 3.0): An integrated software package for population genetics data analysis. Evol Bioinform Online 1:47-50.

Giacomoni EH, Fernández-Stolz GP and Freitas TRO (2008) Genetic diversity in the Pantaneiro horse breed assessed using microsatellite DNA markers. Genet Mol Res 7:261-270.

Hill EW, Bradley DG, Al-Barody M, Ertugrul O, Splan RK, Zakharov I and Cunningham EP (2002) History and integrity of thoroughbred dam lines revealed in equine mtDNA variation. Anim Genet 33:287-294.

Ishida N, Hasegawa T, Takeda K, Sakagami M, Onishi A, Inumaru S, Komatsu M and Mukoyama H (2009) Polymorphic sequence in the D-loop region of equine mitochondrial DNA. Anim Genet 25:215-221.

Ivankovic A, Ramljak J, Konjacic M, Kelava N, Dovc P and Mijic P (2009) Mitochondrial D-loop sequence variation among autochthonous horse breeds in Croatia. Czech J Anim Sci 2009:101-111.

Jansen T, Forster P, Levine MA, Oelke H, Hurles M, Renfrew C, Weber J and Olek K (2002) Mitochondrial DNA and the origins of the domestic horse. Proc Natl Acad Sci U S A 99:10905-10910.

Jimenez LM, Mendez S, Dunner S, Cañón J and Cortés Ó (2012) Colombian Creole horse breeds: Same origin but different diversity. Genet Mol Biol 35:790-796.

Khanshour AM and Cothran EG (2013) Maternal phylogenetic relationships and genetic variation among Arabian horse populations using whole mitochondrial DNA D-loop sequencing. BMC Genet 14:83.

Kumar S, Tamura K and Nei M (2004) MEGA3: Integrated software for Molecular Evolutionary Genetics Analysis and sequence alignment. Brief Bioinform 5:150-163.

Lopes MS, Mendonça D, Cymbron T, Valera M, da Costa-Ferreira J and Machado da Câmara A (2005) The Lusitano horse maternal lineage based on mitochondrial D-loop sequence variation. Anim Genet 36:196-202.

Maciel FC, Bertoli CD, Braccini Neto J, Cobuci JA, Paiva SR and McManus CM (2014) Population structure and genealogical analysis of the Brazilian Crioula Horse. Anim Genet Resour 54:115-125.

McGahern A, Bower MAM, Edwards CJ, Brophy PO, Sulimova G, Zakharov I, Vizuete-Forster M, Levine M, Li S, Mac-
Hugh DE, et al. (2006) Evidence for biogeographic patterning of mitochondrial DNA sequences in Eastern horse populations. Anim Genet 37:494-497.

Mirol PM, Peral García P, Vega-Pla JL and Dulout FN (2002) Phylogenetic relationships of Argentinean Creole horses and other South American and Spanish breeds inferred from mitochondrial DNA sequences. Anim Genet 33:356-363.

Moridi M, Masoudi AA, Vaez Torshizi R and Hill EW (2013) Mitochondrial DNA D-loop sequence variation in maternal lineages of Iranian native horses. Anim Genet 44:209-213.

Notter D (1999) The importance of genetic diversity in livestock populations of the future. J Anim Sci 77:61-69.

Outram AK, Stear NA, Bendrey R, Olsen S, Kasparov A, Zaibert V, Thorpe N and Evershed RP (2009) The earliest horse harnessing and milking. Science 323:1332-1335.

Paiva SR, Facó O, Faria DA, Lacerda T, Barretto GB, Carneiro PLS, Lobo RNB and McManus C (2011) Molecular and pedigree analysis applied to conservation of animal genetic resources: The case of Brazilian Somali hair sheep. Trop Anim Health Prod 43:1449-1457.

Pires DAF, Coelho EGA, Melo JB, Oliverira DAA, Ribeiro MN, Cothran EG and Juras R (2016) Genetic relationship between the Nordestino horse and national and international horse breeds. Genet Mol Res 15:1-8.

Primo A (2004) Conquista e Colonização: A Fantástica História dos Conquistadores Hibéricos e Seus Animais na Era dos Descobrimentos. Editora Movimento, Porto Alegre, 184 p.

Reis SP, Gonçalvez EC, Silva A and Schneider MPC (2008) Genetic variability and efficiency of DNA microsatellite markers for paternity testing in horse breeds from the Brazilian Marajó archipelago. Genet Mol Biol 31:68-72.

Rozas J, Sánchez-DelBarrio JC, Messeguer X and Rozas R (2003) DnaSP, DNA polymorphism analyses by the coalescent and other methods. Bioinformatics 19:2496-2497.

Sereno FTPS, Sereno JRB, Vega-Pla JL, Kelly L and Bermejo JVD (2008) Genetic diversity of Brazilian Pantaneiro horse and relationships among horse breeds. Pesqui Agropec Bras 43:595-604.

Silva ACM, Paiva SR, Albuquerque MSM, Egito AA, Santos SA, Lima FC, Castro ST, Mariante AS, Correa PS and McManus CM (2012) Genetic variability in local Brazilian horse lines using microsatellite markers. Genet Mol Res 11:881-890.

Solis A, Jugo BM, Mériaux JC, Iriondo M, Mazón LI, Aguirre AI, Vicario A and Estomba A (2005) Genetic diversity within and among four south European native horse breeds based on microsatellite DNA analysis: Implications for conservation. J Hered 96:670-678.

Vaughan TA, Ryan, JM and Czaplewski NJ (2010). Mammalogy. $6^{\text {th }}$ edition. Jones and Bartlett Learning, Burlington, $750 \mathrm{p}$.

Zhang T, Lu H, Chen C, Jiang H and Wu S (2012) Genetic diversity of mtDNA D-loop and maternal origin of three Chinese native horse breeds. Asian-Australas J Anim Sci 25:921-926.

\section{Associate Editor: Guillermo Ortí}

License information: This is an open-access article distributed under the terms of the Creative Commons Attribution License (type CC-BY), which permits unrestricted use, distribution and reproduction in any medium, provided the original article is properly cited. 